\title{
REGENERATION OF EGGPLANT (SOLANUM MELONGENA L.) FROM ROOT EXPLANTS
}

\author{
G. FRANKLIN ${ }^{*}$, C. J. SHEEBA ${ }^{2}$, AND G. LAKSHMI SITA ${ }^{1}$ \\ ${ }^{1}$ Department of Microbiology and Cell Biology, Indian Institute of Science, Bangalore 560 012, India \\ ${ }^{2}$ Entomology Research Institute, Loyola College, Chennai 600 034, India
}

(Received 1 December 2002; accepted 2 July 2003; editor W. Y. Soh)

\begin{abstract}
SUMmary
Eggplant (Solanum melongena L.) was efficiently regenerated from cultured roots of 15-d-old seedlings on Murashige and Skoog (MS) medium containing $0.45 \mu M$ thidiazuron and $13.3 \mu M$ 6-benzyladenine. Within $28 \mathrm{~d}$ of culture initiation, induction of organogenic calluses and subsequent differentiation into shoot buds were observed. Shoot buds upon subculture to MS basal medium elongated into healthy shoots. Excised shoots $(2-4 \mathrm{~cm})$ were rooted on Soilrite ${ }^{\circledR}$ irrigated with water either in vitro or in vivo. Plants with well-developed root systems were established under field conditions after hardening in the glasshouse, where they developed into flowering plants and produced mature fruits with viable seeds.
\end{abstract}

Key words: indirect organogenesis; Soilrite ${ }^{\circledR}$; Solanum; thidiazuron.

\section{INTRODUCTION}

Brinjal, the common eggplant, is an important vegetable crop that plays an inevitable role in many diets globally. The ability of eggplant regeneration in tissue culture has allowed the application of biotechnology, particularly the exploitation of somaclonal variation, haploidy, somatic hybridization, and genetic transformation (Collonier et al., 2001). Eggplant has been regenerated via somatic embryogenesis from leaf and cotyledon (Gleddie et al., 1983; Fobert and Webb, 1988; Rao and Singh, 1991; Sharma and Rajam, 1995) and hypocotyl (Matsuoka and Hinata, 1979) explants. Organogenesis from various explants such as leaf, cotyledon, hypocotyl, epicotyl, anther, and isolated microspores has also been reported previously (Isouard et al., 1979; Gleddie et al., 1983; Sharma and Rajam, 1995; Magioli et al., 1998). Formation of embryo-like structures from petiole, lamina, and stem protoplasts was also achieved (Sihachakr and Ducreux, 1987). Furthermore, culture conditions affecting regeneration via organogenesis (Mukherjee et al., 1991) and embryogenesis (Saito and Nishimura, 1994) has been well documented.

Although various sources of explants have been reported for regeneration, there has been no report for regeneration from roots. Root explants are advantageous over other explants in terms of their easy manipulation, higher regeneration potential, and excellent susceptibility for Agrobacterium transformation (Morton and Browse, 1991). This paper reports a regeneration system for elite eggplant varieties commonly cultivated in India by using root explants.

*Author to whom correspondence should be addressed at (present address): Plant Science Research Center, 4223 Wolfe Hall, The University of Toledo, OH 43606-3390, USA; Email: gfranklin71@yahoo.com

\section{Materials and Methods}

Plant material. Seeds of eggplant varieties MEBH 11, MEBH 9, Kalpatru, and Rohini were purchased from Mahyco (Bangalore, India). Uniform healthy seeds were handpicked and washed in running tap water five times. The seeds were then treated with $2 \%$ Bavistin ${ }^{\circledR}$ (BASF India Ltd, India) for $30 \mathrm{~min}$ and then with $70 \%(\mathrm{v} / \mathrm{v})$ ethanol for $30 \mathrm{~s}$ before surface sterilization by dipping into $0.1 \% \mathrm{HgCl}_{2}$ solution for $3 \mathrm{~min}$. Sterilized seeds were placed on sterile wet filter paper or absorbent cotton in Petri dishes and incubated at $25 \pm 2^{\circ} \mathrm{C}$ in the dark for $1 \mathrm{wk}$. Germinated seeds (seedlings) were subcultured on half-strength MS basal medium (Murashige and Skoog, 1962) and incubated under $16 \mathrm{~h}$ photoperiod. Intact root explants obtained from each seedling of different age (15,30, and $45 \mathrm{~d}$ old) were cultured on separate disposable Petri dishes containing $25 \mathrm{ml}$ of culture medium.

Culture media and culture conditions. Plant growth regulators (PGRs) were added to MS basal medium and the $\mathrm{pH}$ was adjusted to 5.8 before autoclaving at $120^{\circ} \mathrm{C}$ for $20 \mathrm{~min}$. Explants were grown on medium solidified with $7 \mathrm{gl}^{-1}$ agar (Bacteriological grade, Himedia, Mumbai, India) and kept under a $16 \mathrm{~h}$ photoperiod, illuminated with cool white fluorescent lamps at a light intensity of $25 \mu \mathrm{mol} \mathrm{s}^{-1} \mathrm{~m}^{-2}$ at $25 \pm 2^{\circ} \mathrm{C}$. Explants with or without shoot primordia were subcultured at 30-d interval to fresh culture medium.

Callus induction and shoot regeneration. MS basal medium was supplemented with different concentrations of thidiazuron (TDZ; 0, 0.45, 2.27, and $4.54 \mu M)$ in combination with either $13.3 \mu M$ 6-benzyladenine (BA) or $1.07 \mu M \alpha$-naphthaleneacetic acid (NAA) for callus induction and subsequent regeneration. The basal medium was used for shoot elongation. The number of shoot buds was counted under a Nikon stereo microscope and the number of elongated shoots was visually examined.

Rooting and hardening. Elongated shoots $(2-4 \mathrm{~cm})$ were excised and transferred to half-strength MS medium containing different concentrations of indole-3-acetic acid (IAA; 0.57, 1.14, and $2.85 \mu M$ ), indole-3-butyric acid (IBA; $0.49,0.98$, and $2.46 \mu M)$ or NAA $(0.54,1.07$, and $2.69 \mu M)$, or wet Soilrite ${ }^{\circledR}$ (Karnataka Explosives Ltd, Bangalore, India) for rooting. Plantlets with developing root systems were transferred to plastic cups containing Soilrite ${ }^{\circledR}$ irrigated with water. Each cup was covered with a polyethylene bag and the plants were hardened for $10 \mathrm{~d}$ by gradually reducing the humidity by making holes in the bag. Hardened plants were 
transplanted into pots containing farmyard manure and soil (1:2) under field conditions.

Stastical analysis. Each treatment of four tested varieties consisted of three replications of 20 samples. Growth regulator treatment and age of the explant were arranged as factorial in a completely randomized design. The response variable was plant regeneration. Data were analyzed by ANOVA $(P \leq 0.05)$ and means were compared using Duncan's multiple range test. Correlation between age of the explant and regeneration was calculated based on a set of random paired observations.

\section{Results and Discussion}

Within 1 wk of culture initiation, roots grown on most media formed callus predominantly from the region in contact with the medium. After another $20 \mathrm{~d}$, meristematic centers appeared on the surface of the callus in the initiation medium containing cytokinin or on subculture to fresh medium, which developed into shoot buds (Fig. 1a). It has been reported that meristematic centers formed on auxin-containing media could differentiate into somatic embryos
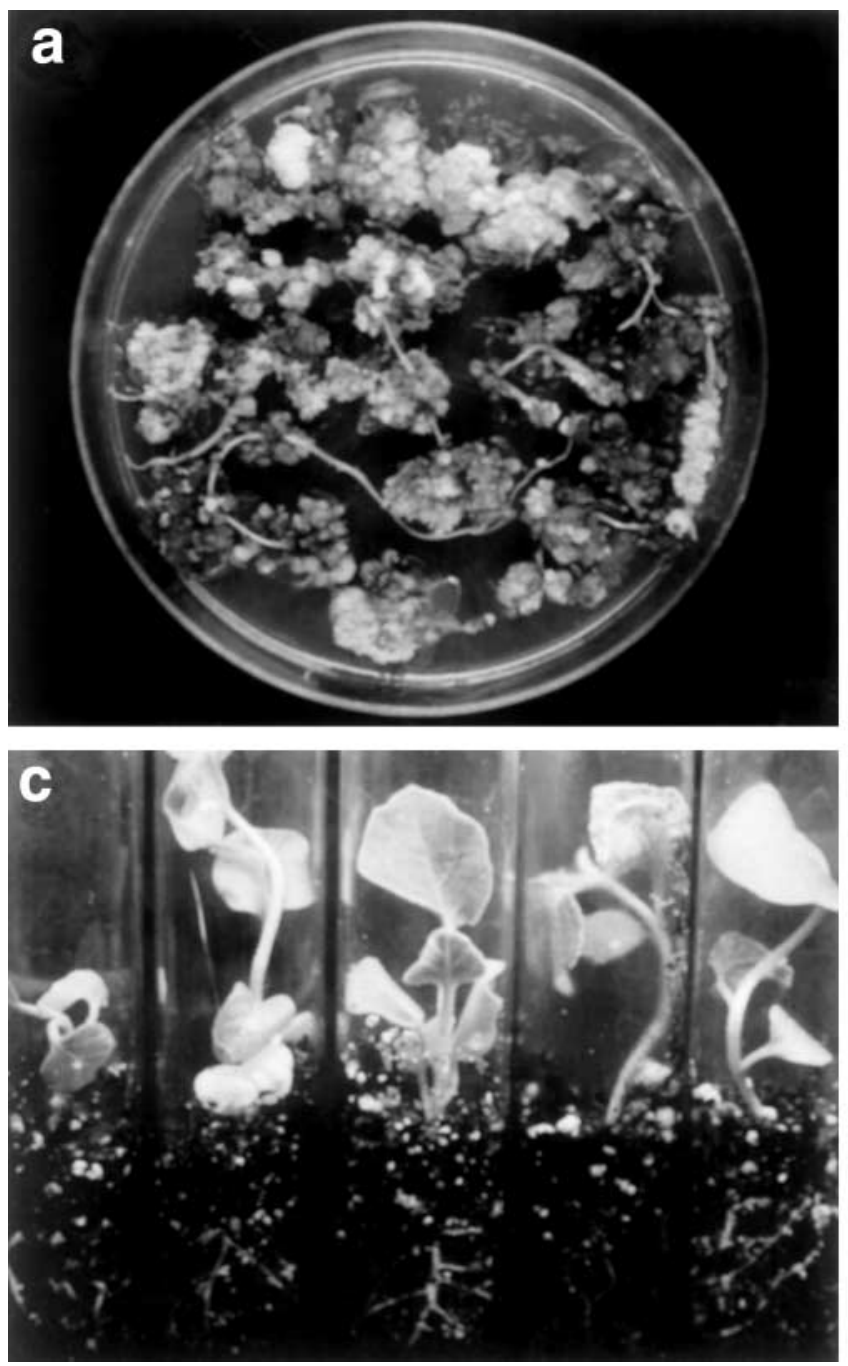

(Gleddie et al., 1983) or embryo-like structures (Sihachakr and Ducreux, 1987) within $15 \mathrm{~d}$

The morphogenetic response of root explants of MEBH 11 on different PGRs is presented in Table 1. PGR combinations significantly affected regeneration $(P=0.00425)$. Even though explants formed calluses and shoots on a wide range of hormonal combinations, the best response occurred in the medium containing $0.45 \mu M$ TDZ and $13.3 \mu M \mathrm{BA}$, regardless of the age of explants. Although root explants derived from different eggplant varieties differed in terms of the frequency of regeneration, they exhibited a more or less similar response in all other parameters such as optimal media, pattern of callusing, shoot induction, elongation, and rooting. However, a high genotypic variability in organogenesis and embryogenesis of various explants such as hypocotyl, cotyledon, and leaf discs has been reported previously (Gleddie et al., 1983; Sharma and Rajam, 1995).

The explant age is a critical factor significantly affecting callus induction and subsequent shoot bud formation $(P=0.00052)$. A negative correlation was observed between regeneration and explant
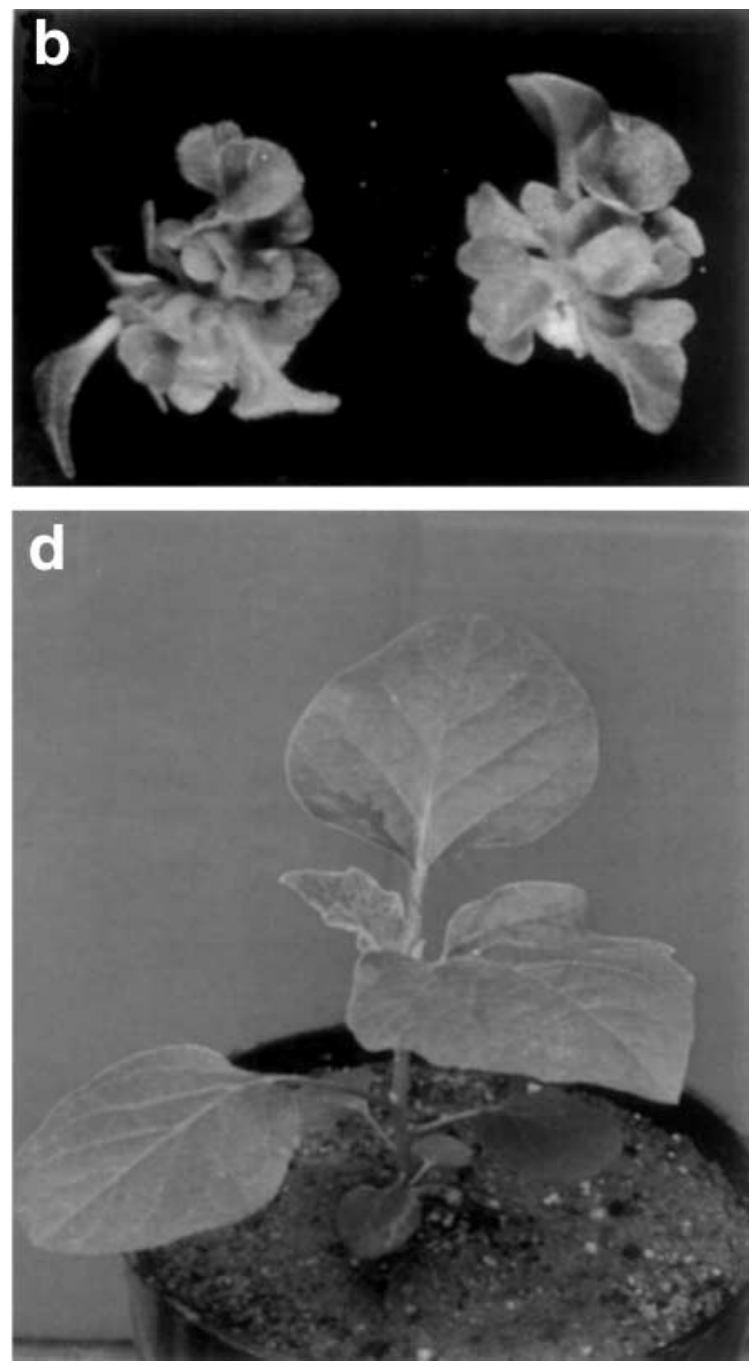

FIG. 1. Regeneration of eggplant (var. MEBH 11) from root explants. $a$, Regeneration of shoot buds from roots of 15-d-old seedlings on MS medium supplemented with $0.45 \mu M$ TDZ and $13.3 \mu M \mathrm{BA} ; b$, elongated shoots with two root-derived callus clumps; $c$, shoots derived from TDZ-containing medium formed roots on Soilrite ${ }^{\circledR}$ irrigated with water; $d$, plant established in the pot after hardening. 
TABLE 1

EFFECT OF PGRs ON SHOOT REGENERATION FROM ROOT EXPLANTS OF THE GENOTYPE MEBH 11 AT DIFFERENT AGES

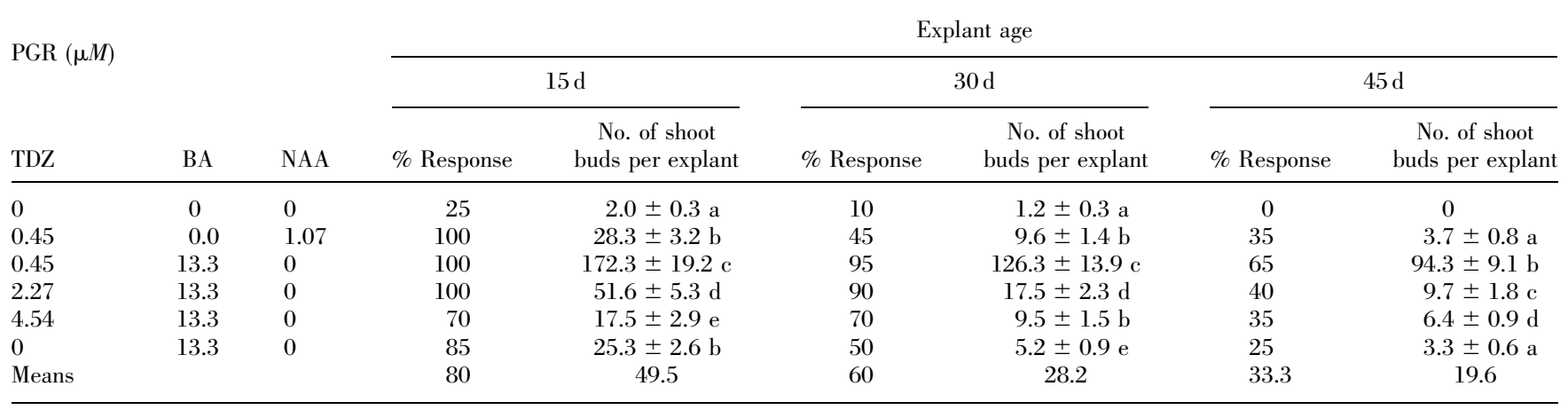

Means $( \pm \mathrm{SE})$ in a column with different letters are significantly different $(P \leq 0.05$, Duncan's multiple range test).

age $(\gamma=-0.76)$. Among the various ages of explants, 15-d-old root explants scored the maximum of 18-20 calluses, each forming 175-200 shoot buds. Shoot elongation was not synchronous in cultures of cytokinin-containing media. In some cultures few shoots elongated, whereas others remained diminutive. When organogenic calluses from initial media were subcultured on hormone-free medium, each callus gave rise to six to eight elongated shoots (Fig. 1b). In general, a total of 108-160 elongated shoots could be obtained from a single explant using this approach. In contrast, only 23 shoots out of 75-100 shoot buds were elongated from cotyledon explants in a previous study (Magioli et al., 1998). This variation in shoot elongation may be due to the competition between hundreds of buds of an explant for light and nutrient within a limited space. Prolonged culture of morphogenic calluses on media containing TDZ often resulted in the formation of short, vitrified shoots, as reported by Magioli et al. (1998).

Successful rooting of regenerated shoots is a prerequisite for micropropagation. Elongated shoots from media containing TDZ did not form roots after being transferred to root induction media containing auxin, while a low frequency of shoots from cultures growing on basal medium or media with BA formed roots (Table 2). Similar rooting inhibition for shoots derived from cultures grown in the presence of TDZ (Magioli et al., 1998) or BA (Sharma and Rajam, 1995) has also been reported previously. However, in peanut, TDZ-induced shoots were effectively rooted at low concentrations of IBA (Gill and Ozias-Akins, 1999). In this study, we observed that shoots could be easily rooted by directly transferring onto Soilrite ${ }^{\circledR}$ under in vitro or in vivo conditions (Fig. 1c). The number of roots formed on each shoot was also significantly higher in Soilrite ${ }^{\circledR}$ than in other rooting media. Rooting of micro shoots treated with IBA at the cut ends and placed directly in the soil mix has been reported (Das et al., 1990; Jain et al., 1993). The addition of $2.46 \mu M$ IBA to Soilrite ${ }^{\circledR}$ promoted callus formation at the cut ends of shoots derived from different media. Kartha et al. (1981) reported that IBA facilitated rapid development of roots, whereas basal medium promoted the formation of callus at the shoot base in legumes regenerated on TDZ-containing media. It was observed that there was a variation in callus-forming and regeneration potential in different varieties (Table 3).

Plants with the well-developed root systems were transplanted to plastic cups and covered with polyethylene bags to maintain
TABLE 2

ROOTING RESPONSE OF REGENERATED SHOOTS OF THE GENOTYPE MEBH 11 ON DIFFERENT ROOTING MEDIA

\begin{tabular}{lccc}
\hline Medium & $\begin{array}{c}\% \\
\text { Rooting }\end{array}$ & $\begin{array}{c}\text { No. of roots } \\
\text { per shoot }\end{array}$ & $\begin{array}{c}\text { Days taken for } \\
\text { root induction }\end{array}$ \\
\hline $1 / 2 \mathrm{MS}+2.46 \mu M$ IBA & 45 & $3.5 \pm 0.4 \mathrm{a}$ & $46.2 \pm 3.2 \mathrm{a}$ \\
$1 / 2 \mathrm{MS}+2.69 \mu M$ NAA & 15 & $2.5 \pm 1.2 \mathrm{~b}$ & $52.5 \pm 2.4 \mathrm{~b}$ \\
Soilrite $^{\circledR}+$ sterile water & 100 & $9.3 \pm 1.1 \mathrm{c}$ & $15.7 \pm 1.8 \mathrm{c}$ \\
Soilrite $^{\circledR}+2.46 \mu M$ IBA & 0 & 0 & - \\
\hline
\end{tabular}

$1 / 2 \mathrm{MS}$, half-strength MS.

Means $( \pm \mathrm{SE})$ in a column with different letters are significantly different $(P \leq 0.05$, Duncan's multiple range test $)$.

TABLE 3

MORPHOGENETIC RESPONSES OF ROOT EXPLANTS OBTAINED FROM DIFFERENT EGGPLANT GENOTYPES ON MS MEDIUM CONTAINING $0.45 \mu M$ TDZ AND $13.3 \mu M$ BA

\begin{tabular}{lcr}
\hline Variety & \% Response & $\begin{array}{c}\text { Mean shoot buds } \\
\text { per explant }\end{array}$ \\
\hline MEBH 11 & 100 & $172.3 \pm 19.2 \mathrm{a}$ \\
MEBH 9 & 100 & $151.5 \pm 11.2 \mathrm{~b}$ \\
Kalpatru & 100 & $152.8 \pm 13.9 \mathrm{~b}$ \\
Rohini & 100 & $122.7 \pm 9.5 \mathrm{c}$ \\
\hline
\end{tabular}

Means $( \pm \mathrm{SE})$ in a column with different letters are significantly different $(P \leq 0.05$, Duncan's multiple range test).

humidity. Reducing the humidity by making slits on the wrap simultaneously increased the hardiness of the plants. Such plants, hardened over $10 \mathrm{~d}$, were established in pots containing farmyard manure and soil irrigated with water under field conditions (Fig. 1d), where $95 \%$ of plants survived. The regenerated plants also grew into mature fruit-bearing plants.

In this study, we report an 8-fold increase in the production of shoots per explant when compared with the results of a previous study (Magioli et al., 1998). Results also show that explant age and PGRs in the medium are crucial for plant regeneration from root explants of eggplant. 


\section{ReFERENCES}

Collonier, C.; Fock, I.; Kashyap, V.; Rotino, G. L.; Dunay, M. C.; Lian, Y.; Mariska, I. K.; Rajam, M. V.; Servaes, A.; Ducreux, G.; Sihachakr, D. Application of biotechnology in eggplant. Plant Cell Tiss. Organ Cult. 65:91-107; 2001.

Das, S. C.; Barman, T. S.; Singh, R. Plant regeneration and establishment in nursery. Assam Rev. Tea News 79:24-27; 1990.

Gill, R.; Ozias-Akins, P. Thidiazuron-induced highly morphogenetic callus and high frequency regeneration of fertile peanut (Arachis hypogaea L.) plants. In Vitro Cell. Dev. Biol. Plant 35:445-450; 1999.

Gleddie, S.; Keller, W.; Setterfield, G. Somatic embryogenesis and plant regeneration from leaf explants and cell suspensions of Solanum melongena L (eggplant). Can. J. Bot. 61:656-666; 1983.

Fobert, P. K.; Webb, D. T. Effect of polyamines, polyamine precursors and polyamine inhibitors on somatic embryogenesis of eggplant (Solanum melongena L.) cotyledons. Can. J. Bot. 66:1734-1742; 1988.

Isouard, G.; Raquim, C.; Demarly, Y. Obtention de plantes haploides et diploides par culture in vitro antheres d'aubergine (Solanum melongena L.). C. R. Acad. Sci. Paris 288:987-989; 1979.

Jain, S. M.; Das, S. C.; Barman, T. S. Enhancement of root induction from in vitro regenerated shoots of tea (Camellia sinensis L.). Proc. Ind. Natl Sci. Acad. B59:623-628; 1993.

Kartha, K. K.; Pahl, K.; Leung, N. L.; Mroginski, L. A. Plant regeneration from meristems of grain legumes: soybean, cowpea, peanut, chickpea, and bean. Can. J. Bot. 59:1671-1679; 1981.
Magioli, C.; Rocha, A. P. M.; de Oliveira, D. E.; Mansur, E. Efficient shoot organogenesis of eggplant (Solanum melongena L.) induced by thidiazuron. Plant Cell Rep. 17:661-663; 1998.

Matsuoka, H.; Hinata, K. NAA induced organogenesis and embryogenesis in hypocotyl callus of Solanum melongena L. J. Exp. Bot. 30:363-370; 1979.

Morton, L.; Browse, J. Facile transformation of Arabidopsis. Plant Cell Rep. 10:235-239; 1991.

Mukherjee, S. K.; Rathinasabapathi, B.; Gupta, N. Low sugar and osmotic requirements for shoot regeneration from leaf pieces of Solanum melongena L. Plant Cell Tiss. Organ Cult. 25:13-16; 1991.

Murashige, T.; Skoog, F. A revised medium for rapid growth and bioassays with tobacco tissue cultures. Physiol. Plant. 15:473-497; 1962.

Rao, P. V. L.; Singh, B. Plantlet regeneration from encapsulated somatic embryos of hybrid Solanum melongena L. Plant Cell Rep. 10:7-11; 1991.

Saito, T.; Nishimura, S. Improved cultural conditions for somatic embryogenesis using an aseptic ventilative filter in eggplant (Solanum melongena L.). Plant Sci. 102:205-211; 1994.

Sharma, P.; Rajam, M. V. Genotype, explant and position effects on organogenesis and embryogenesis in eggplant (Solanum melongena L.). J. Exp. Bot. 46:135-141; 1995.

Sihachakr, D.; Ducreux, G. Cultural behavior of protoplasts from different organs of eggplant (Solanum melongena L.) and plant regeneration. Plant Cell Tiss. Organ Cult. 11:179-188; 1987. 